\title{
Application of Copper as Stabiliser in Aluminium Assisted Transfer of Titanium in Submerged Arc Welding of Carbon Steel
}

\author{
Theresa Coetsee *(D) and Frederik De Bruin
}

check for updates

Citation: Coetsee, T.; De Bruin, F. Application of Copper as Stabiliser in Aluminium Assisted Transfer of Titanium in Submerged Arc Welding of Carbon Steel. Processes 2021, 9 , 1763. https://doi.org/10.3390/ pr9101763

Academic Editor: Vincent Terrasson

Received: 17 August 2021

Accepted: 28 September 2021

Published: 1 October 2021

Publisher's Note: MDPI stays neutral with regard to jurisdictional claims in published maps and institutional affiliations.

Copyright: (C) 2021 by the authors. Licensee MDPI, Basel, Switzerland. This article is an open access article distributed under the terms and conditions of the Creative Commons Attribution (CC BY) license (https:/ / creativecommons.org/licenses/by/ $4.0 /)$.
Department of Materials Science and Metallurgical Engineering, University of Pretoria, Pretoria 0002, South Africa; fjdb.1953@gmail.com

* Correspondence: theresa.coetsee@up.ac.za

Abstract: The element transfer of Ti from molten flux to the weld metal is limited to less than $310 \mathrm{ppm}$ Ti in the submerged arc welding of carbon steel. This limitation is due to the high oxygen partial pressure prevailing at the molten flux-weld pool interface. Our previous study illustrated that the use of $\mathrm{Al}$ powder in combination with Ti powder improves the transfer of Ti to the weld metal to $4 \%$ $\mathrm{Ti}$, whilst maintaining 509 ppm O in the weld metal. The weld metal ppm O should be controlled at 200 to 500 ppm O to maintain weld metal toughness. In this study, the addition of Cu powder with $\mathrm{Ti}$ and $\mathrm{Al}$ powder is applied to illustrate the stabiliser effect of $\mathrm{Cu}$ in the weld pool. The role of $\mathrm{Cu}$ as weld pool stabiliser is due to its decrease of the temperature required to melt Ti into the weld pool, so increasing the quantity of metal powder melted into the weld pool. The weld metal composition improved to $5.1 \% \mathrm{Ti}, 3.6 \% \mathrm{Cu}$, and $371 \mathrm{ppm} \mathrm{O}$. Thus, the role of $\mathrm{Al}$ in controlling the partial oxygen pressure at the molten flux-weld pool interface is maintained in the presence of $\mathrm{Cu}$ powder.

Keywords: oxygen potential; titanium; aluminium; copper; metal powder; submerged arc welding

\section{Introduction}

Submerged arc welding (SAW) is applied in the welding of thick steel plates in heavy engineering industries such as shipbuilding and pressure vessel construction [1]. In the SAW process, electrical and chemical parameters are combined to form an arc between the weld wire tip and the steel base plate. Raw unmelted flux and molten flux (slag) cover the arc to form the arc cavity. Weld wire and flux are continuously fed through the welding head arrangement as it moves along the weld. In the arc cavity the molten weld wire metal droplets are transferred into the weld pool as complex physical and chemical interactions of heat and mass transfer occur [1]. Chemical reactions continue in the trailing molten weld pool of molten flux and steel, until the steel is solidified as weld metal [2,3]. Flux typically contains a mixture of various oxides and fluorides, and the latter is usually added as $\mathrm{CaF}_{2}$. An important empirically determined flux composition guideline is to ensure that the flux basicity index (BI), expressed in Equation (1), exceeds 1.5 to ensure low hydrogen and low total oxygen content in the weld metal $[4,5]$.

$$
\mathrm{BI}=\frac{\left[\% \mathrm{CaF}_{2}+\% \mathrm{CaO}+\% \mathrm{MgO}+\% \mathrm{BaO}+\% \mathrm{SrO}+\% \mathrm{Na}_{2} \mathrm{O}+\% \mathrm{~K}_{2} \mathrm{O}+\% \mathrm{Li}_{2} \mathrm{O}+0.5(\% \mathrm{MnO}+\% \mathrm{FeO})\right]}{\left[\% \mathrm{SiO}_{2}+0.5\left(\% \mathrm{Al}_{2} \mathrm{O}_{3}+\% \mathrm{TiO}_{2}+\% \mathrm{ZrO}_{2}\right)\right]}
$$

It is well established that an excessive quantity of oxygen is initially added to the molten weld wire droplets from the arc cavity gas phase, up to 2000-3000 ppm O [6,7]. This initial oxygen quantity in the metal droplets is sourced from the decomposition of less stable oxides at the high temperatures prevailing in the plasma arc, and so flux chemistry is used to manage oxygen transfer to the weld metal from the plasma arc [8]. The plasma arc stability of oxides was determined in welding tests made with binary $\mathrm{CaF}_{2}$-oxide flux mixtures, from high to low stability: $\mathrm{CaO}, \mathrm{K}_{2} \mathrm{O}, \mathrm{Na}_{2} \mathrm{O}$ and $\mathrm{TiO}_{2}, \mathrm{Al}_{2} \mathrm{O}_{3}, \mathrm{MgO}, \mathrm{SiO}_{2}$, and 
$\mathrm{MnO}$ [8]. Therefore, increased addition of $\mathrm{CaF}_{2}$ to the flux will dilute the quantity of low stability oxides in the flux to ensure lower ppm $\mathrm{O}$ in the weld metal. Weld metal oxygen must be controlled within a relatively narrow band to ensure high weld metal impact toughness. Both too low $(<200 \mathrm{ppm} \mathrm{O})$ and too high $(>500 \mathrm{ppm})$ weld metal oxygen contents were found to be detrimental to weld metal impact toughness [9].

Previous work confirmed that the excess oxygen transferred from the arc cavity reacts with the molten steel at the plasma-weld pool interface to form $\mathrm{FeO}$. This $\mathrm{FeO}$ ends up in the molten flux. The correlation of increased $\mathrm{FeO}$ in the molten flux with increased weld metal ppm O is well known [10-15]. In our previous work we illustrated the use of metal powders ( $\mathrm{Ti}$ and $\mathrm{Al}$ ) to control the oxygen potential at the flux-weld pool interface, as presented by the quantity of $\mathrm{FeO}$ in the molten flux, to meet the requirements of sufficient ppm $\mathrm{O}$ in the weld metal and increased Ti content in the weld metal [16].

Ti-oxide inclusions form active nucleation sites for acicular ferrite (AF) microstructure formation in the weld metal to improve weld metal strength and toughness [17,18]. Furthermore, it has been established that increased Ti content (from $30 \mathrm{ppm}$ to $1300 \mathrm{ppm} \mathrm{Ti}$ ) in the weld metal increases AF formation by changing Ti-oxide inclusion chemistry [19]. When $\mathrm{TiO}_{2}$ is increased in the SAW flux to increase Ti in the weld metal, only a limited quantity of $\mathrm{Ti}(310 \mathrm{ppm} \mathrm{Ti})$ is transferred to the weld metal $[20,21]$. Increased weld metal Ti content of $700 \mathrm{ppm}$ was reported in gas shielded fluxed cored arc welding [22]. In this work we use copper metal powder, in addition to the Ti and Al metal powder, as used in our previous study, to improve the transfer of $\mathrm{Ti}$ and $\mathrm{Al}$ into the weld pool. The application of unconstrained (not fluxed cored wire) metal powders in SAW is well illustrated as applied to increasing welding productivity in welding joint applications, and in cladding applications [23-25]. However, limited published studies were reported on the application of unconstrained metal powders to generate a highly alloyed weld metal joint in SAW. Knowledge on the behaviour of the different alloying elements in the SAW process in terms of interaction with oxygen and added powder alloy elements will provide better process development choices to attain efficient alloying from the metal powders.

Copper is added in small quantities $(0.32 \% \mathrm{Cu})$ to high-strength low-alloy steel to enhance AF formation associated with Al-Ti-oxide inclusions, and thus improve the weld metal impact toughness [26]. Higher copper addition levels are used in carbon steels, and additions of up to $4 \% \mathrm{Cu}$ are made to chrome-manganese stainless steels to improve steel corrosion resistance and still maintain good weldability [27]. Limited work has been done on welding of high-entropy alloys (HEAs) and compositionally complex alloys (CCAs), [28]. Therefore, a method for welding HEA plates by generating a closely matched weld metal composition is an important milestone for utilizing HEAs and CCAs in manufacturing. Due to SAW being a high productivity welding method, this method should be included in such work. This approach ties in with our current study since increased attempts are made to use $\mathrm{Cu}$ in HEA design. For example, the expensive Co in the $\mathrm{Al}_{x} \mathrm{CoCrFeNi}$ alloy may be replaced with inexpensive $\mathrm{Cu}$ [29]. However, the addition of copper to weld wire causes work hardening of the weld wire so that the wire is not easily formed, or easily used as feed wire material in the welding process [30]. From the above discussion it is clear that copper may find different materials property applications in different steel and alloy grades and in the welding of these material grades. Furthermore, copper feed in the form of metal powder offers a solution to the practical materials problem of feeding work hardening copper containing wire. The purpose of this work is to illustrate the application of copper metal powder addition in SAW to stabilise the $\mathrm{Al}$ and Ti powder metal uptake into the weld metal, and still control the ppm $\mathrm{O}$ in the weld metal within the target of 200-500 ppm O.

\section{Materials and Methods}

Welding experiments were conducted with and without metal powders ( $\mathrm{Al}, \mathrm{Ti}$, and $\mathrm{Cu}$ ) to illustrate the process concept of oxygen potential control at the molten flux-weld pool interface in the presence of $\mathrm{Cu}$. 
SAW welding tests were made as bead-on-plate runs onto steel plates of $350 \mathrm{~mm}$ length, $12 \mathrm{~mm}$ plate thickness and $300 \mathrm{~mm}$ plate width. Weld heat input was $2.0 \mathrm{~kJ} / \mathrm{mm}$ (500 A, 28 V, $42 \mathrm{~cm} /$ minute) welded DCEP (Direct Current Electrode Positive) with $3.2 \mathrm{~mm}$ diameter wire. Structural steel grade EN 10025-2 was used as base plate material. The weld wire major element levels are from the supplier's specification sheet as supplied by Afrox Ltd., South-Africa. The rest of the element analyses in Table 1 were obtained from laboratory analyses. The base plate steel was analysed by optical emission spectroscopy (OES). The oxygen content in the base plate and weld wire was analysed by combustion method.

Table 1. Steel plate and weld wire compositions.

\begin{tabular}{lccccccccc}
\hline & $\mathbf{\% C}$ & $\mathbf{\%} \mathbf{S i}$ & $\mathbf{\% M n}$ & ${ }^{*} \mathbf{O}$ & ${ }^{*} \mathbf{A} \mathbf{l}$ & ${ }^{*} \mathbf{P}$ & ${ }^{*} \mathbf{S}$ & ${ }^{*} \mathbf{T i}$ & ${ }^{*} \mathbf{C u}$ \\
\hline Plate & 0.120 & 0.155 & 1.340 & 7 & 67 & 19 & 7 & 5 & 30 \\
Wire & 0.110 & 0.137 & 0.990 & 3 & 0 & 9 & 23 & 0 & 140 \\
\hline${ }^{*}$ ppm. & & & & &
\end{tabular}

The welded plate was sectioned to remove cross section samples of the weld metal for major element analyses by OES, and total oxygen content analyses by combustion method. Due to higher concentrations of $\mathrm{Ti}$ and $\mathrm{Al}$ in the weld metal, compared to low carbon steel, $\mathrm{Al}$ and Ti contents were analysed by ICP-OES (Inductively coupled plasma optical emission spectrometry). A Zeiss crossbeam 540 FEG (Field emission gun) SEM (scanning electron microscope) was used in this study. EDS (energy dispersive spectrometer) analyses were done at $20 \mathrm{kV}$ and $5.6 \mathrm{~mm}$ working distance.

Commercial agglomerated flux of composition in Table 2 was used in the welding experiments. This is an Aluminate Basic flux (Basicity Index $(\mathrm{BI})=1.4$ ) and was extensively analysed as reported previously [31]. The metal powder additions were sourced as Al $(99.7 \% \mathrm{Al})$ supplied by Sigma-Aldrich, Ti $(99.5 \% \mathrm{Ti})$ supplied by PLS Technik GmbH \& Co. and $\mathrm{Cu}(99.8 \% \mathrm{Cu})$ supplied by Goodfellow.

Table 2. Flux composition (mass $\%$ ).

\begin{tabular}{cccccccccc}
\hline $\mathrm{MnO}$ & $\mathrm{CaO}$ & $\mathrm{SiO}_{2}$ & $\mathrm{Al}_{\mathbf{2}} \mathbf{O}_{3}$ & $\mathrm{CaF}_{2}$ & $\mathrm{MgO}$ & $\mathrm{FeO}$ & $\mathrm{TiO}_{2}$ & $\mathrm{Na}_{2} \mathrm{O}$ & $\mathrm{K}_{\mathbf{2}} \mathrm{O}$ \\
\hline 6.8 & 0.1 & 19.6 & 24.9 & 17.9 & 22.2 & 2.4 & 1.0 & 1.6 & 0.2 \\
\hline
\end{tabular}

\section{Results}

The weld metal compositions for the three scenarios, weld metal formed without metal powder addition as the Base Case (BC), weld metal formed with $10 \mathrm{~g} \mathrm{Al}$ and $10 \mathrm{~g}$ Ti metal powder addition (MP1), and weld metal formed with $10 \mathrm{~g} \mathrm{Al}, 10 \mathrm{~g}$ Ti and $10 \mathrm{~g} \mathrm{Cu}$ metal powder addition (MP3), are summarised in Table 3.

Table 3. Weld metal compositions.

\begin{tabular}{lccccccccc}
\hline & \%C & \%Si & \%Mn & ${ }^{*} \mathbf{O}$ & \%Al & ${ }^{*} \mathbf{P}$ & ${ }^{*} \mathbf{S}$ & \% Ti & \%Cu \\
\hline Base & 0.110 & 0.260 & 1.300 & 499 & 0.032 & 22 & 11 & 0.005 & 0.11 \\
Case & & & & & & & & \\
MP1 & 0.130 & 1.050 & 1.690 & 509 & 0.980 & 28 & 17 & 4.370 & 0.11 \\
MP3 & 0.074 & 1.040 & 1.640 & 371 & 5.260 & 15 & 12 & 5.110 & 3.59 \\
\hline${ }^{*}$ ppm. & & & & & & &
\end{tabular}

Comparison of the BC and MP weld metal analyses in Table 3 clearly shows increased levels of $\mathrm{Si}, \mathrm{Mn}, \mathrm{Al}$, and $\mathrm{Ti}$ in the MP1 and increased $\mathrm{Cu}$ in the MP3 weld metal due to added metal powders used in SAW. The ppm O in the BC and MP1 welds are similar at $499 \mathrm{ppm}$ without powder additions and $509 \mathrm{ppm}$ with $\mathrm{Al}$ and Ti powder additions. However, when $\mathrm{Cu}$ is also added to the weld (MP3) the weld metal ppm O is lowered to $371 \mathrm{ppm}$ O. 
SEM micrographs and EDS analyses were used to confirm increased Ti content in the weld metal for MP1 and MP3. The MP1 EDS analyses were already described previously [16]. Similarly, the EDS analyses results for the MP3 weld metal analyses areas in Figure 1, as displayed in Table 4, correspond well to the bulk weld metal analyses in Table 3. $\mathrm{MnO}$ and $\mathrm{SiO}_{2}$ were reduced by $\mathrm{Al}$ powder according to reactions (2) and (3). Similarly, FeO is reduced from the molten flux via reaction (4).

$$
\begin{gathered}
3\left(\mathrm{SiO}_{2}\right)+4(\mathrm{Al})=3(\mathrm{Si})+2\left(\mathrm{Al}_{2} \mathrm{O}_{3}\right) \Delta \mathrm{H}_{2000}{ }^{\circ} \mathrm{C}=-82.1 \mathrm{~kJ} / \mathrm{mol} \mathrm{Al} \\
3(\mathrm{MnO})+2(\mathrm{Al})=3(\mathrm{Mn})+\left(\mathrm{Al}_{2} \mathrm{O}_{3}\right) \Delta \mathrm{H}_{2000}{ }^{\circ} \mathrm{C}=-248.4 \mathrm{~kJ} / \mathrm{mol} \mathrm{Al} \\
3(\mathrm{FeO})+2(\mathrm{Al})=3(\mathrm{Fe})+\left(\mathrm{Al}_{2} \mathrm{O}_{3}\right) \Delta \mathrm{H}_{2000}{ }^{\circ} \mathrm{C}=-416.5 \mathrm{~kJ} / \mathrm{mol} \mathrm{Al}
\end{gathered}
$$

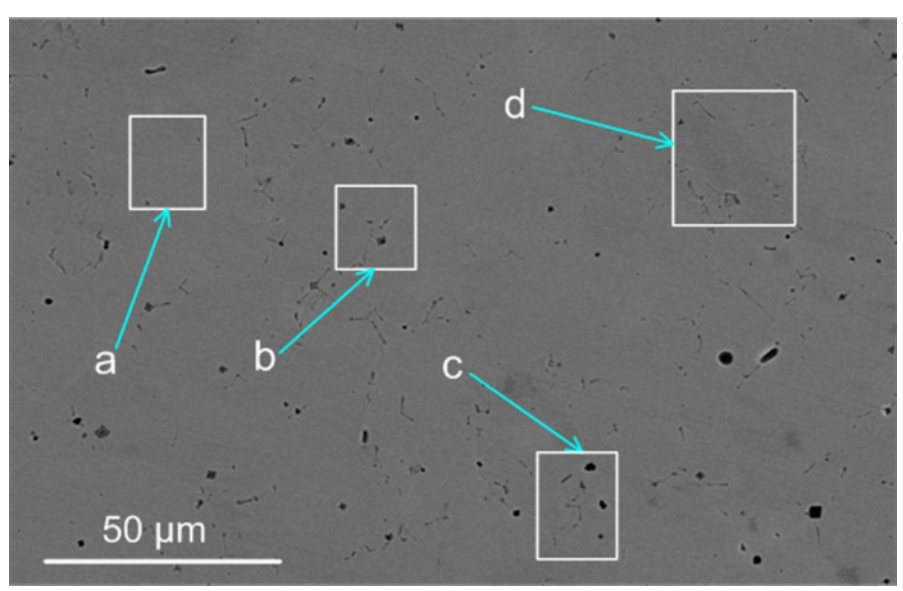

Figure 1. SEM micrograph of weld metal analysed areas $(\times 1500)$.

Table 4. SEM-EDS analyses of marked areas in Figure 1 (mass $\%)$.

\begin{tabular}{ccccccc}
\hline & $\mathbf{S i}$ & $\mathbf{M n}$ & $\mathbf{A l}$ & $\mathbf{T i}$ & $\mathbf{F e}$ & $\mathbf{C u}$ \\
\hline $\mathrm{a}$ & 0.85 & 1.72 & 4.29 & 3.38 & 85.8 & 3.9 \\
$\mathrm{~b}$ & 0.88 & 1.87 & 4.18 & 4.63 & 84.4 & 4.1 \\
$\mathrm{c}$ & 0.96 & 1.68 & 4.63 & 4.69 & 84.1 & 3.9 \\
$\mathrm{~d}$ & 0.95 & 1.78 & 4.03 & 4.53 & 84.8 & 3.9 \\
\hline
\end{tabular}

Increased Si and Mn content in the MP1 and MP3 weld metal, compared to the BC weld metal, confirms that sufficient contact time was established between $\mathrm{Al}$ powder and molten flux to enable reactions (2) and (3) to proceed forward. The $\mathrm{Al}_{2} \mathrm{O}_{3}$ products formed in these two reactions most likely ended up in the molten flux since the reactions occurred at the molten flux-weld pool interface. Most importantly, sufficiently reducing conditions were maintained in the presence of $\mathrm{Al}$ powder to dissolve large quantities of $\mathrm{Ti}$ powder in the weld pool, and not oxidise all the Ti powder to Ti-oxides at the molten flux-weld pool interface. The ppm $\mathrm{O}$ quantities in the MP1 and MP3 weld metal analyses are too small in proportion to the weld metal Ti content for all $\mathrm{Ti}$ to be present in the form of oxides. Therefore, oxide inclusion formation preference is expected to be set by the thermodynamic likelihood of reactions between the steel elements $\mathrm{Al}, \mathrm{Ti}, \mathrm{Si}, \mathrm{Mn}$, and oxygen in the weld pool steel.

\section{Discussion}

The lowered ppm $\mathrm{O}$ and increased $\mathrm{Al}$ content in the MP3 weld metal, in association with added $\mathrm{Cu}$ powder, indicates a modification in the reactions due to $\mathrm{Cu}$ powder addition. The melting point of pure $\mathrm{Al}$, Ti and $\mathrm{Cu}$ are $660{ }^{\circ} \mathrm{C}, 1660^{\circ} \mathrm{C}$ and $1083^{\circ} \mathrm{C}$. Clearly from the weld metal analyses in Table 3, more metal powder was added into the MP3 weld metal, in 
the presence of $\mathrm{Cu}$, than was added into the MP1 weld metal. The mass quantities of Ti and $\mathrm{Al}$ added to the weld metals MP3 and MP1 are calculated in the following section.

From each welding test, the mass of metal added to the weld plate was recorded. For each weld metal cross section, the areas above and below the base plate level were measured to determine the dilution ratio, namely the mass proportions of (wire + metal powder) vs. base plate contributed to the weld metal. The dilution ratio percentage $\left(\% D R_{(w i r e+M P)}\right)$ is expressed in Equation (5). The mass of $\mathrm{Al}, \mathrm{Ti}$, and $\mathrm{Cu}$ added to the weld metal was calculated from Equations (5) to (7), using the weld metal composition in Table 3 as input to Equation (7). Equation (7) is expressed for the Al mass added, but similar calculations were made for Ti and $\mathrm{Cu}$ using the weld metal composition in Table 3.

$$
\begin{gathered}
\% \mathrm{DR}_{(\text {wire }+\mathrm{MP})}=\left(\frac{\mathrm{A}_{(\text {wire }+\mathrm{MP})}}{\mathrm{A}_{(\text {wire }+\mathrm{MP})}+\mathrm{A}_{\mathrm{BP}}}\right) \times 100 \\
\mathrm{~m}_{\mathrm{WM}}=\left(\mathrm{m}_{\text {wire }}+\mathrm{m}_{\mathrm{MP}}\right) \times\left(\frac{100}{\% \mathrm{DR}_{(\text {wire }+\mathrm{MP})}}\right) \\
(\text { gram } \mathrm{Al} \mathrm{WM})=\left(\mathrm{m}_{\mathrm{WM}}\right) \times\left(\frac{\% \mathrm{Al}_{\mathrm{WM}}}{100}\right)
\end{gathered}
$$

WM, weld metal; MP, metal powder; BP, base plate; Wire, weld wire; m, mass (gram); A, area $\left(\mathrm{mm}^{2}\right)$

The mass of metal powders incorporated into the weld metal are summarised in Table 5 , in addition to the mass values of the total weld metal, base plate and wire. Although the mass of Ti melted into the weld metal is similar for MP1 and MP3 weld metal, the mass of Al melted into the MP3 weld metal is higher, and the total mass of metal powders melted into the MP3 weld metal is significantly higher at 12.8 grams vs. 5.5 grams melted into MP1. This effect of increased metal powder incorporation into the weld metal for the same welding energy input is due to the metal stabiliser role of copper as set out in the following discussion.

Table 5. Post weld masses and metal powder mass added to weld metal.

\begin{tabular}{cccccccccc}
\hline & Al $\mathbf{( g )}$ & Ti $(\mathbf{g})$ & $\mathbf{C u}(\mathbf{g})$ & $\begin{array}{c}* \text { Powder } \\
\mathbf{( g )}\end{array}$ & Wire (g) & $\begin{array}{c}\text { Base } \\
\text { Plate }(\mathbf{g})\end{array}$ & $\begin{array}{c}\text { Weld } \\
\text { Metal (g) }\end{array}$ & Slag (g) & \%DR $($ wire+MP) \\
\hline Base Case & 0 & 0 & 0 & 0 & 33.7 & 67.6 & 135 & 50 \\
MP1 & 1.0 & 4.5 & 0 & 5.5 & 47.0 & 50.4 & 103 & 41.5 & 51 \\
MP3 & 4.8 & 4.7 & 3.3 & 12.8 & 54.7 & 23.7 & 91 & 42.9 & 74 \\
\hline
\end{tabular}

* Total $\mathrm{Al}$, $\mathrm{Ti}$, and $\mathrm{Cu}$ powder added to weld metal.

The binary alloy phase diagrams displayed in Figures $2-4$ were taken from the FactSage 7.3 thermochemical software documentation to illustrate the chemical effect of $\mathrm{Cu}$ [32]. The stabiliser effect by $\mathrm{Cu}$ is due to its extensive lowering of the Ti liquidus temperature from $1660^{\circ} \mathrm{C}$ to as low as $1265^{\circ} \mathrm{C}$ at the mol ratio of Ti/ $(\mathrm{Cu}+\mathrm{Ti})=0.65$ at the red arrow in Figure 2. This mol ratio corresponds approximately to that of the MP3 alloy composition in Table 3. The $\mathrm{Cu}$ metal powder added to the weld pool serve as stabiliser of Ti in the weld pool by decreasing the temperature required to melt Ti into the weld pool. 


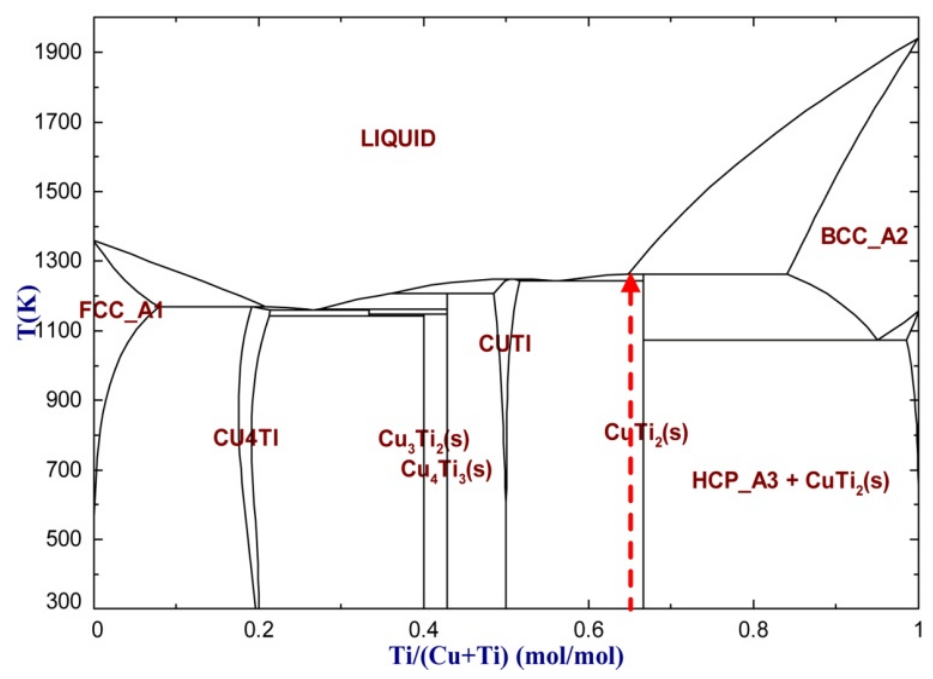

Figure 2. Cu-Ti phase diagram (FactSage 7.3).

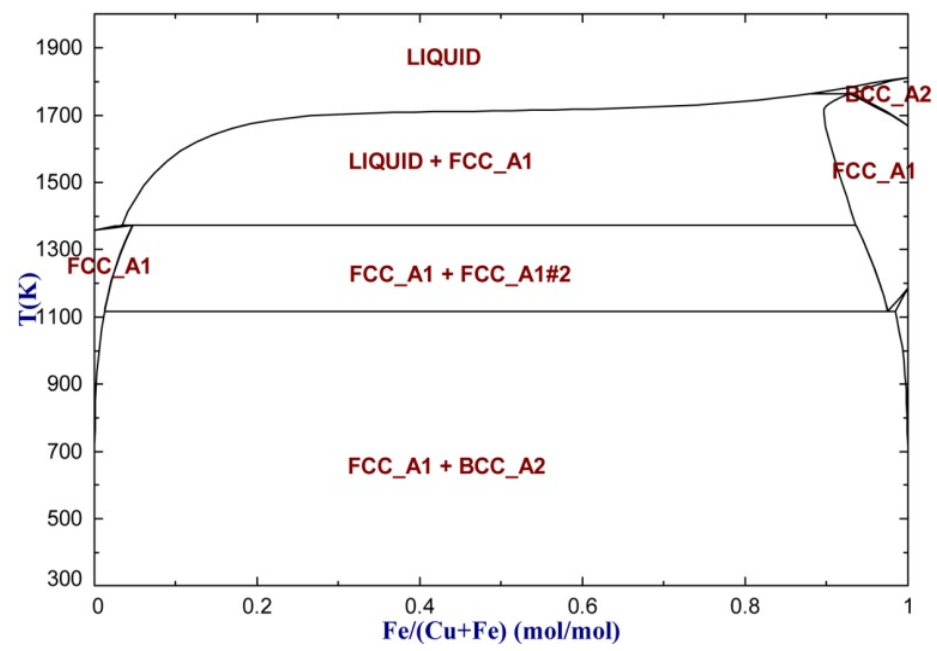

Figure 3. Cu-Fe phase diagram (FactSage 7.3).

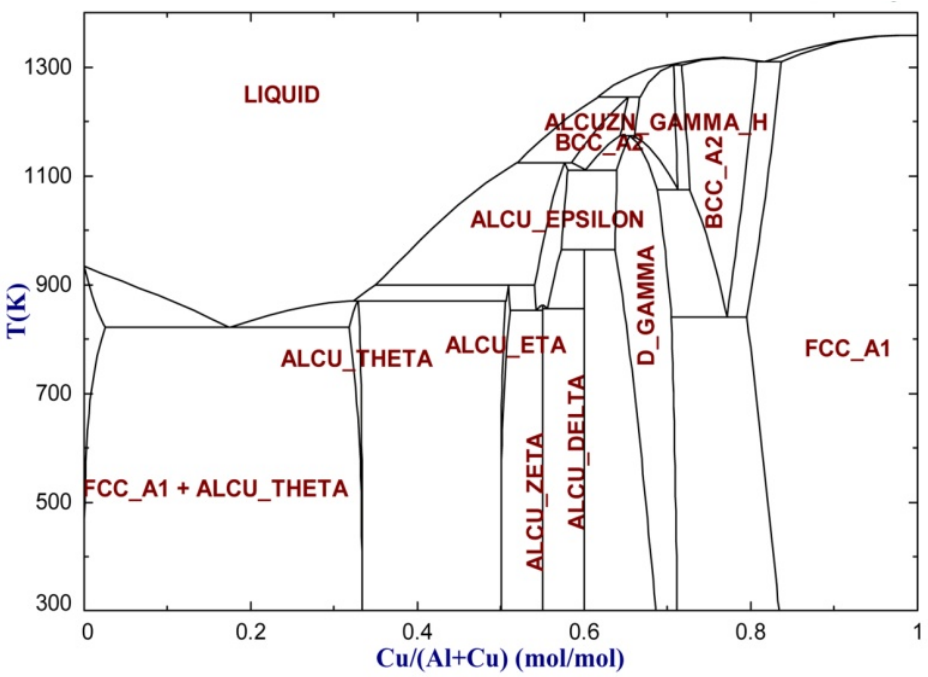

Figure 4. $\mathrm{Cu}-\mathrm{Al}$ phase diagram (FactSage 7.3).

The $\mathrm{Cu}-\mathrm{Fe}$ and $\mathrm{Cu}-\mathrm{Al}$ phase diagrams in Figures 3 and 4 indicate only a slight liquidus lowering effect of small quantities of copper added to Fe or Al. $\mathrm{Cu}$ does not have a high 
affinity for oxygen, as compared to $\mathrm{Al}$, and therefore remains in the weld pool as a metal to perform its role of lowering the Ti metal powder liquidus temperature. Furthermore, once the weld pool is formed, the cooling time of the weld pool may be extended if the weld pool steel chemistry has a lowered solidus temperature. This appears to be the case as displayed in Figure 5 as the solidification curve for MP3 weld metal shows the solidus temperature as $1311^{\circ} \mathrm{C}$, compared to the solidus temperature of MP1 weld metal at $1363{ }^{\circ} \mathrm{C}$. These curves were calculated in the Equilib module of FactSage 7.3, using the FToxid and FSstel databases [32].

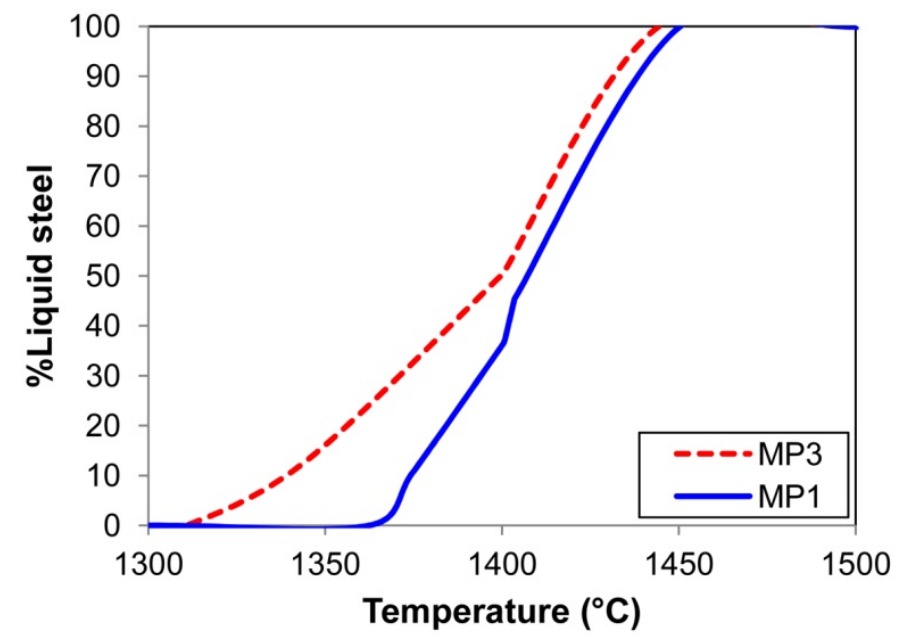

Figure 5. Solidification curves for MP1 and MP3 weld metal compositions (FactSage 7.3).

Increased silicon and manganese content in the MP weld metal analyses in Table 3, as compared to the $\mathrm{BC}$ weld metal, confirms that $\mathrm{SiO}_{2}$ and $\mathrm{MnO}$ were reduced from the molten flux by the added $\mathrm{Al}$ powder. The mass of Mn and Si added to the MP weld metals, relative to the $\mathrm{BC}$ weld metal nominal composition, was calculated from the weld metal mass and the dilution ratio values in Table 5, as illustrated in Equation (8) for Mn. The mass of $\mathrm{Si}$ added relative to the $\mathrm{BC}$ value may be calculated by using the \% $\mathrm{Si}$ values, instead of the \%Mn values, in Equation (8). The square bracketed terms of Equation (8) represent the calculation of the $\mathrm{BC}$ weld metal nominal composition.

$$
\mathrm{m}_{\mathrm{Mn}}=\left(\mathrm{m}_{\mathrm{wm}}\right)\left(\frac{\% \mathrm{Mn}_{\mathrm{WM}}}{100}-\left[\frac{\% \mathrm{DR}_{\text {wire }}}{100} \times \frac{\% \mathrm{Mn}_{\text {wire }}}{100}\right]-\left[\left(1-\frac{\% \mathrm{DR} \text { wire }}{100}\right) \times \frac{\% \mathrm{Mn}_{\mathrm{BP}}}{100}\right]\right)
$$

The mass of $\mathrm{SiO}_{2}$ and $\mathrm{MnO}$ reduced from the flux by $\mathrm{Al}$ powder via reactions (2) and (3) are summarised in Table 6. These values are the mass values of Mn and Si calculated from Equation (8), expressed as the oxides $\mathrm{MnO}$ and $\mathrm{SiO}_{2}$. The $\mathrm{kJ}$ heat generated from each reduction reaction as calculated from the exothermic reaction heat values $\left(\Delta \mathrm{H}_{2000^{\circ} \mathrm{C}}\right)$ displayed next to reactions (2) and (3) are also summarised in Table 6. The exothermic heat quantity values are expressed as weld metal temperature increase values by using the heat capacity of steel $(0.460 \mathrm{~kJ} / \mathrm{kg} \mathrm{K})$. These values for MP1 and MP3 weld metal are similar, at $-5.3 \mathrm{~kJ}$ and $-4.5 \mathrm{~kJ}$ exothermic heat evolved, potentially heating the weld metal by $112{ }^{\circ} \mathrm{C}$ and $107^{\circ} \mathrm{C}$, respectively. These are minimum values since the extent of reaction (4) is not known, and this reaction definitely proceeded in part since reaction (4) is used to control the partial oxygen pressure at the weld pool-slag interface [16]. Since the same welding parameters and the same welding flux was used it is expected that the same quantity of oxygen was initially present in the weld pool, as transferred via the weld wire metal droplets from the arc cavity. 
Table 6. Exothermic heat from aluminium reduction reactions (2) and (3).

\begin{tabular}{cccccccc}
\hline & $\begin{array}{c}\mathrm{SiO}_{2} \\
(\mathbf{g})\end{array}$ & $\begin{array}{c}\mathrm{MnO} \\
(\mathbf{g})\end{array}$ & $\begin{array}{c}\mathrm{Al} \\
\mathbf{( g )}\end{array}$ & $\begin{array}{c}\text { Reaction } \\
\mathbf{( 2 )} \\
\mathbf{( k J )}\end{array}$ & $\begin{array}{c}\text { Reaction } \\
\mathbf{( 3 )} \\
(\mathbf{k J})\end{array}$ & $\begin{array}{c}\text { Reactions } \\
(\mathbf{2}) \&(3) \\
(\mathbf{k J})\end{array}$ & $\begin{array}{c}\text { Weld } \\
\mathbf{M T}\left({ }^{\circ} \mathbf{C}\right)\end{array}$ \\
\hline $\mathrm{MP1}$ & 2.0 & 0.7 & 1.4 & -3.6 & -1.6 & -5.3 & 112 \\
$\mathrm{MP3}$ & 1.7 & 0.6 & 1.2 & -3.2 & -4.5 & -4.5 & 107 \\
\hline
\end{tabular}

The importance of the similar numbers in Table 6 is that the difference in melting rate of metal powders into MP1 and MP3 weld metal is unlikely due to different extents of the exothermic reactions of $\mathrm{Al} / \mathrm{SiO}_{2}$ and /or $\mathrm{Al} / \mathrm{MnO}$ as displayed in reactions (2) and (3). Since the same weld heat input settings of $\mathrm{V}, \mathrm{A}$ and travel speed were applied in all the tests, the time taken for the weld pool to solidify should be the same if the weld pool compositions were similar [33]. From the differences in weld metal ppm O in MP1 at $509 \mathrm{ppm} \mathrm{O}$ vs. $371 \mathrm{ppm} \mathrm{O}$ in MP3, it appears that the weld pool solidification time was longer in the case of Al-Ti-Cu powder additions, as compared to only Al-Ti powder additions. The added copper lowers the alloy steel solidus temperature (as illustrated in Figure 5) and so increases the time available for oxide inclusions to float out of the weld pool liquid steel to the molten flux-weld pool interface, where the inclusions are then incorporated into the molten flux.

Therefore, our initial SAW reaction flow diagram as illustrated previously, is updated as shown in Figure 6 to include the stabiliser behaviour of copper metal powder [16]. The reaction flow diagram in Figure 6 illustrates the reaction sites and reaction sequence in the SAW process. Reaction steps A to E are as presented from previous works as reported in literature. Al powder added to the weld pool serves to control the oxygen potential at the molten flux-weld pool interface by reducing $\mathrm{FeO}$ via reaction (4) in the text, which is similar to reaction $G$ in Figure 6. These reduction reactions are exothermic and release heat from chemical energy into the weld pool to further facilitate melting and dissolution of Ti.

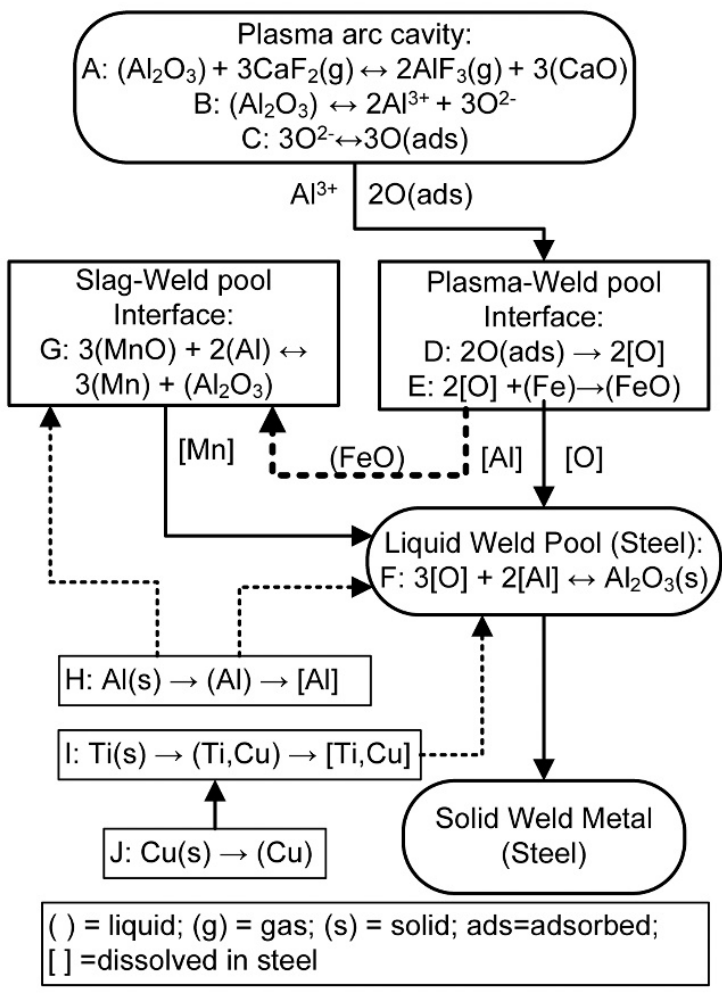

Figure 6. SAW reaction flow diagram with $\mathrm{Al}$, $\mathrm{Ti}$, and $\mathrm{Cu}$ powder addition reactions. 
Despite the added $\mathrm{Al}$ and Ti powder in the weld pool, the weld metal oxygen content remained relatively high at 509 ppm O in MP1 and 371 ppm O in MP3 weld metal. The addition of copper powder does not appear to influence the weld metal oxygen content via chemical reactions since copper has a low affinity for oxygen. As concluded in our previous study, in the presence of Al and Ti metal powders, the weld metal oxygen content is not set by equilibrium de-oxidation reactions in the weld pool since the quantity of dissolved oxygen, captured as inclusions in the solid weld metal, was much higher than the $\mathrm{Al}^{-} \mathrm{Al}_{2} \mathrm{O}_{3}$ and $\mathrm{Ti}^{-} \mathrm{Ti}_{2} \mathrm{O}_{3}$ de-oxidation reaction equilibrium values of $10 \mathrm{ppm} \mathrm{O}$ at $0.1 \% \mathrm{Al}$ and $30 \mathrm{ppm}$ $\mathrm{O}$ at $4 \% \mathrm{Ti}$ in steel at $1600{ }^{\circ} \mathrm{C}$ [34]. Gas-slag-metal equilibrium has been illustrated to hold for SAW in the absence of metal powders as discussed elsewhere [10,35].

The same mechanism of oxygen transfer from the arc cavity to the weld pool appears to hold for both instances, Al and Ti powder added in MP1 and Al and Ti powder in combination with $\mathrm{Cu}$ powder addition in MP3, since the ppm $\mathrm{O}$ in the MP1 and MP3 weld metal is much higher than would be set by $\mathrm{Al}-\mathrm{Al}_{2} \mathrm{O}_{3}$ and $\mathrm{Ti}^{-} \mathrm{Ti}_{2} \mathrm{O}_{3}$ de-oxidation reaction equilibria. The reduced oxygen potential at the molten flux-weld pool interface prevents oxidation of Ti powder to Ti-oxides, and ensures that the Ti is melted with $\mathrm{Cu}$ and then dissolved into the weld pool, reaction I. Since there is an excess of $\mathrm{Al}$ added, some of the $\mathrm{Al}$ also dissolves into the weld pool (reaction $\mathrm{H}$ ). Both dissolved $\mathrm{Ti}$ and $\mathrm{Al}$ react with oxygen in the steel to form inclusions (reaction F). Reactions I and J illustrate the role of $\mathrm{Cu}$ as stabiliser whereby $\mathrm{Cu}$ first forms a low temperature alloy with Ti to decrease the temperature required for melting Ti into the weld pool.

The results presented here confirm that the oxygen potential at the molten flux-weld pool interface is sufficiently controlled by $\mathrm{Al}$ powder addition, even when $\mathrm{Cu}$ powder is added to the weld pool. The lowered oxygen potential at the molten flux-weld pool interface enhances Ti powder transfer into the weld pool, without interfering with oxygen transfer from the plasma arc to the weld pool. Copper metal powder addition to the weld pool acts as a stabiliser metal by lowering the Ti liquidus temperature from $1660^{\circ} \mathrm{C}$ to as low as $1265{ }^{\circ} \mathrm{C}$. The copper metal powder added to the weld pool serves as stabiliser of Ti in the weld pool by decreasing the temperature required for melting Ti into the weld pool.

\section{Conclusions}

1. The results presented here confirm that the oxygen potential at the molten flux-weld pool interface is sufficiently controlled by $\mathrm{Al}$ powder addition, even when $\mathrm{Cu}$ powder is added to the weld pool.

2. The oxygen potential was controlled by $\mathrm{Al}$ addition without interfering with oxygen transfer from the plasma arc to the weld pool, resulting in $371 \mathrm{ppm} \mathrm{O}$ in the weld metal vs. $509 \mathrm{ppm} \mathrm{O}$ in the absence of $\mathrm{Cu}$ powder addition.

3. The $\mathrm{Cu}$ metal powder added to the weld pool serve as stabiliser of Ti in the weld pool by decreasing the temperature required for melting Ti into the weld pool.

4. Weld metal of $5.1 \% \mathrm{Ti}, 5.3 \% \mathrm{Al}$ and $3.6 \% \mathrm{Cu}$ was formed with $\mathrm{Cu}$ powder addition vs. $4 \% \mathrm{Ti}$ and $0.98 \% \mathrm{Al}$ in the absence of $\mathrm{Cu}$ powder addition.

5 . The quantity of metal powder melted into the weld pool increased with the addition of $\mathrm{Cu}$ powder.

Author Contributions: F.D.B. conceptualised the work; F.D.B. and T.C. executed the experiments, interpreted the data, and prepared the manuscript. All authors have read and agreed to the published version of the manuscript.

Funding: This research was funded in part by the National Research Foundation of South Africa, grant number BRIC171211293679.

Institutional Review Board Statement: Not applicable.

Informed Consent Statement: Not applicable.

Data Availability Statement: Not applicable. 
Conflicts of Interest: The authors declare no conflict of interest. The funders had no role in the design of the study; in the collection, analyses, or interpretation of data; in the writing of the manuscript; or in the decision to publish the results.

\section{References}

1. Sengupta, V.; Havrylov, D.; Mendex, P.F. Physical phenomena in the weld zone of submerged arc welding-A Review. Weld. J. 2019, 98, 283-313.

2. Chai, C.S.; Eagar, T.W. Slag-metal equilibrium during submerged arc welding. Metall. Trans. B. 1981, 12, 539-547. [CrossRef]

3. Mitra, U.; Eagar, T.W. Slag-metal reactions during welding: Part I. Evaluation and reassessment of existing theories. Metall. Trans. B 1991, 22, 65-71. [CrossRef]

4. Eagar, T.W. Sources of weld metal oxygen contamination during submerged arc welding. Weld. J. 1978, 57, 76-80.

5. Tuliani, S.S.; Boniszewski, T.; Eaton, N.F. Notch toughness of commercial submerged arc weld metal. Weld. Met. Fabr. 1969, 37, 327-339.

6. Polar, A.; Indacochea, J.E.; Blander, M. Electrochemically generated oxygen contamination in submerged arc welding. Weld. J. 1990, 69, 68-74.

7. Lau, T.; Weatherly, G.C.; Mc Lean, A. The sources of oxygen and nitrogen contamination in submerged arc welding using $\mathrm{CaO}-\mathrm{Al}_{2} \mathrm{O}_{3}$ based fluxes. Weld. J. 1985, 64, 343-347.

8. Chai, C.S.; Eagar, T.W. Slag metal reactions in binary $\mathrm{CaF}_{2}$-metal oxide welding fluxes. Weld. J. 1982, 61, $229-232$.

9. Dallam, C.B.; Liu, S.; Olson, D.L. Flux composition dependence of microstructure and toughness of submerged arc HSLA weldments. Weld. J. 1985, 64, 140-152.

10. Coetsee, T.; Mostert, R.J.; Pistorius, P.G.H.; Pistorius, P.C. The effect of flux chemistry on element transfer in Submerged Arc Welding: Application of thermochemical modelling. Mater. Res. Technol. 2021, 11, 2021-2036. [CrossRef]

11. Mitra, U.; Eagar, T.W. Slag metal reactions during submerged arc welding of alloy steels. Metall. Trans. B 1984, 15, $217-227$. [CrossRef]

12. Mitra, U.; Eagar, T.W. Slag-metal reactions during welding: Part II. Theory. Metall. Trans. B 1991, 22, 73-81. [CrossRef]

13. Zhang, J.; Coetsee, T.; Wang, C. Element transfer behaviors of fused $\mathrm{CaF}_{2}-\mathrm{SiO}_{2}$ fluxes subject to high heat input submerged arc welding. Metall. Trans. B 2020, 51, 16-21. [CrossRef]

14. Zhang, J.; Coetsee, T.; Dong, H.; Wang, C. Element transfer behaviors of fused $\mathrm{CaF}_{2}-\mathrm{SiO}_{2}-\mathrm{MnO}$ fluxes under high heat input submerged arc welding. Metall. Trans. B 2020, 51, 885-890. [CrossRef]

15. Zhang, J.; Coetsee, T.; Dong, H.; Wang, C. Element Transfer Behaviors of fused $\mathrm{CaF}_{2}-\mathrm{TiO}_{2}$ Fluxes in EH36 Shipbuilding steel during high heat input Submerged Arc Welding. Metall. Trans. B 2020, 51, 1953-1957. [CrossRef]

16. Coetsee, T.; De Bruin, F.J. Improved titanium transfer in Submerged Arc Welding of carbon steel through aluminium addition. Miner. Process Extr. Metall. Rev. 2021. [CrossRef]

17. Koseki, T.; Thewlis, G. Inclusion assisted microstructure control in C-Mn and low alloy steel welds. Mater. Sci. Technol. 2005, 21, 867-879. [CrossRef]

18. Sarma, D.S.; Karasev, A.V.; Jonsson, P.G. On the role of non-metallic inclusions in the nucleation of acicular ferrite in steels. ISIJ Int. 2009, 49, 1063-1074. [CrossRef]

19. Wang, B.; Liu, X.; Wang, G. Inclusion characteristics and acicular ferrite nucleation in Ti-containing weld metals of X80 pipeline steel. Metall. Trans. A 2018, 49, 2124-2138. [CrossRef]

20. Zhang, J.; Leng, J.; Wang, C. Tuning weld metal mechanical responses via welding flux optimization of $\mathrm{TiO}_{2}$ content: Application into EH36 shipbuilding steel. Metall. Trans. B 2019, 50, 2083-2087. [CrossRef]

21. Kohno, R.; Takamo, T.; Mori, N.; Nagano, K. New fluxes of improved weld metal toughness for HSLA steels. Weld. J. 1982, 61, 373-380.

22. Oh, D.W.; Olson, D.L.; Frost, R.H. The influence of Boron and Titanium on low-carbon steel weld metal. Weld. J. 1990, 69, 151-158.

23. Bailey, N. Submerged Arc Welding ferritic steels with alloyed metal powder. Weld. J. 1991, 70, 187-206.

24. Nand, S.; Singh, P.K. Effect of addition of metal powder on deposition rate, mechanical properties, and metallographic property of weld joints during Submerged Arc Welding process. J. Mach. Form. Technol. 2015, 6, 159-168.

25. Tušek, J.; Suban, M. High-productivity multiple-wire Submerged-Arc Welding and cladding with metal-powder addition. J. Mater. Process. Technol. 2003, 133, 207-213. [CrossRef]

26. Wan, X.L.; Wu, K.M.; Huang, G.; Nune, K.C.; Li, Y.; Cheng, L. Toughness improvement by Cu addition in the simulated coarse-grained heat-affected zone of high-strength low-alloy steels. Sci. Technol. Weld. Join. 2016, 21, 295-302. [CrossRef]

27. De, S.K.; Srikanth, S.; Saxena, A.K.; Jha, B.K. Copper bearing steels from SAIL and its application. Int. J. Metall. Eng. 2016, 5, 1-8.

28. Rhode, M.; Richter, T.; Schroepfer, D.; Manzoni, A.M.; Scneider, M.; Laplanche, G. Welding of high-entropy and compositionally complex alloys-an overview. Weld. World. 2021, 65, 1645-1659. [CrossRef]

29. Guo, S.; $\mathrm{Ng}$, X.; Liu, C.T. Anomalous solidification microstructures in Co-free $\mathrm{Al}_{\mathrm{x}} \mathrm{CrCuFeNi}_{2}$ high-entropy alloys. Alloy. Compd. 2013, 557, 77-81. [CrossRef]

30. Patel, D.; Soman, S.N. Develop a flux cored wire for submerged arc welding of Ni-Mo low alloy steel. Sadhana 2020, $45,127$. [CrossRef] 
31. Coetsee, T. Phase chemistry of Submerged Arc Welding (SAW) fluoride based slags. Mater. Res. Technol. 2020, 9, 9766-9776. [CrossRef]

32. Bale, B.R.; Chartrand, P.; Degterov, S.A.; Errikson, G. FactSage thermochemical software and databases. Calphad 2002, 26, 189-228. [CrossRef]

33. Kluken, A.O.; Grong, Ø. Mechanisms of inclusion formation in Al-Ti-Si-Mn deoxidized steel weld metals. Metall. Trans. B 1989, 20, 1335-1349. [CrossRef]

34. Jung, I.; Decterov, S.A.; Pelton, A.D. Computer applications of thermodynamic databases to inclusion engineering. ISIJ Int. 2004, 44, 527-536. [CrossRef]

35. Zhang, J.; Coetsee, T.; Basu, S.; Wang, C. Impact of gas formation on the transfer of Ti and O from $\mathrm{TiO}_{2}$-bearing basic fluoride fluxes to submerged arc welded metals: A thermodynamic approach. Calphad 2020, 71, 102195. [CrossRef] 